UDC 330.322 .3

JEL Classification: D20, I25, 010

DOI: $10.15587 / 2312-8372.2018 .147277$

\section{Pishenina T. Vlasova K.}

\title{
DEVELOPMENT OF INFORMATION IMPERATIVES OF SOCIO-ECONOMIC DEVELOPMENT OF UKRAINE
}

Об’єктом дослідження є особливості розвитку і впровадження сучасного інформаційного забезпечення системи управління сочіально-економічним розвитком. Одним з найбільш проблемних місць є визначення оцінки ефективності інформаційної системи. Прочес очінювання інформаційної системи пов'язаний зі складністю та тривалістю впровадження системи інформаційного забезпечення управління сочіальноекономічним розвитком.

Проведено аналіз сучасного стану інформачійного забезпечення управління підприємствами. Розвиток сучасних інформаційних систем дозволяє розкрити потенційні можливості сочіально-економічного комплексу держави у забезпеченні сталого розвитку. Визначено основні характеристики впровадження, збільшення рівня конкурентоспроможності інноваційної продукиї або послуги при застосуванні інформаційних систем управління підприємством. Інформаційні системи стимулюють впровадження інноваційних процесів раціонального використання ресурсного потенціалу, що гарантує формування інформаційних імперативів і прийняття прогресивних управлінських рішень для змічнення конкурентних переваг України на світових ринках. Впровадження системи інформащійного забезпечення на підприємстві ускладнено впливом ендогенних та екзогенних факторів та є складною та тривалою процедурою.

При проведенні досліджень застосовувалися загальнонаукові та спеціальні методи дослідження: аналізу і синтезу, аналогій і порівняльного аналізу, метод декомпозицї і деталізації процесів. 3 використанням цих методів проведено попередній аналіз сучасних інформаційних технологій та їх імплементацї у систему державного управління сочіально-економічним комплексом як складною економічною системою. А також визначенні рівні ризиків і проведена оцінка їх впливу на результат управління.

В ході дослідження використовувалися інформаційно-інноващійні підходи до процесу прийняття управлінських рішень. Визначено основні напрями оцінки ефективності соціально-економічних проектів при впровадженні системи інформаційного забезпечення. Ці напрями дозволяють оцінити економічні результати при створенні сощіальних заходів щодо підвищення інформаційного забезпечення системи управління. А також розробку і виконання соціально-економічних проектів з урахуванням основних ресурсів та факторів виробництва інноваційної продукцї. Завдяки щьому забезпечується можливість якісно контролювати витрати виробнищтва на кожному етапі впровадження системи інформаційного забезпечення.

Ключові слова: інформаційні імперативи, соціально-економічний розвиток, сочіальний проект, система управління, інновачійна продукціл.

\section{Introduction}

Among the large number of new management theories, they are actively developing in the modern period, information technologies and their implementation are not always top-priority.

Theories consider the vision of accumulation of knowledge, but ignoring the creation of new informational approaches based on experience and the possibility of transactional communications in a single information space. Therefore, not enough attention is paid to the spread of this experience within the organization, on innovative products, in modern services and in existing enterprise management systems.

A large information network allows to create special technologies that provide business protection. The formation of a new intellectual potential at the basis of modern information systems allows to ensure its viability and competitiveness. Therefore, the development of information imperatives of socio-economic development is relevant, it is a strategic tool and forms the basis for the sustainable development of the state.

\section{The object of research and its technological audit}

The object of research is the features of the development and implementation of modern information support of the socio-economic development management system.

The development of modern information systems allows to reveal the potential possibilities of the socio-economic complex of the state in ensuring sustainable development. Information systems stimulate the introduction of innovative processes of rational use of the resource potential, guarantees the formation of information imperatives and the adoption of progressive management decisions to strengthen Ukraine's competitive advantages in world markets.

One of the most problematic places is determination of the efficiency evaluation of the information system in the state management of the socio-economic development of the country. The process of evaluating an information system is associated with the complexity and duration of the implementation of modern information management systems. 


\section{The aim and objectives of research}

The aim of research is identification of the modernization processes of enterprises in the implementation of modern information and innovative technologies.

To achieve this aim it is necessary to solve the following objectives:

1. To determine the level and main stages of informatization.

2. To identify the importance of the organizational component for the efficiency of the implementation of modernization changes in the system of modern information processes.

3. To show the features of the main tasks of the implementation of modernization processes and propose methods for solving problems in this direction.

\section{Research of existing solutions of the problem}

The information and innovation paradigm forms the significant competitive advantages of the modern enterprise management system. Such competitive advantages are based on the knowledge and skills of staff. Intellect is enhanced by the use of modern information technologies and is the dominant socio-economic development [1, 2]. This means that the efficiency of management in the system of sectoral convergence with information technology in the formation of information databases and the creation of a unified information network significantly affects labor productivity and a significant increase in profits. And also strengthens the competitive advantages of the organization. Information technologies are assets that must be created taking into account exogenous and endogenous factors and be introduced into a modern management system [3, 4].

The manufacturability of education systems based on information technologies is provided by state imperatives for the generation of high innovation activity and the state of the system of educational technologies when introducing modern information systems [5].

The qualitative parameters of the scientific heritage form a modern view of the global scientific experience in the implementation of information technologies [6, 7].

A large number of scientific publications show the importance of questions of comparative assessments of the introduction of information technology [8, 9]. Modern information systems are the basis for the sustainable development of world scientific progress [10].

Among the main directions of solving the problem of the formation of information imperatives of socio-economic development and the definition of basic resources may be the allocation of socio-economic and regulatory aspects $[11,12]$.

But they do not address the issue of the strategic importance of modern information systems as the basis for the sustainable development of the state [13].

The work [14] is devoted to the essential concepts of innovation management, but the knowledge economy does not solve information support issues as a key component of the prospects for building an information network [15]. An alternative solution to the problem of the information cluster, described in studies [16, 17], is devoted to transformational processes in society. However, the described parameters do not have actual evidence regarding the implementation of information systems in the socioeconomic complex of the state. The imperatives of enterprise development presented in [18] do not emphasize the importance of economic development strategy as a key component of the socio-economic complex of Ukraine.

The authors of [19] consider integration processes as imperatives for the development of a modern economy, although the basis of the socio-economic complex is the components that make it possible to form effective government solutions to solve socio-economic problems.

According to the authors of $[20,21]$, the innovative way of development of Ukraine is considered through solving the problem of the economy, but these studies do not confirm the possibility of implementing the developed solutions in the context of the socio-economic component.

The new paradigm of building management systems [22], as well as the methodology for managing social capital in the conditions of the formation of the information economy, consider these issues very meaningfully, but do not provide the fundamental basis for the formation of information imperatives [23].

Thus, the results of the analysis allow to conclude that it is necessary to continue scientific research on the development and formation of information imperatives in the system of the socio-economic development of the state.

\section{Methods of research}

General scientific and special research methods are used in this research:

- analysis and synthesis - for:

1) a preliminary analysis of modern information technologies and their implementation in the system of public administration of the socio-economic complex as a complex economic system;

2) determining the level of risks and assessing their impact on the management result;

3 ) study of the features of information support for analyzing the influence of uncertainties on public administration processes;

- analogies and comparative analysis - to determine the ratios of the estimated characteristics of existing corporate information management systems;

- decomposition method:

1) allows to divide the problem in accordance with the new tasks of modernization of the socio-economic complex and apply model studies on the design of an information database on the main components;

2) to detail the modeling of management processes in parallel work with market research and marketing.

Such methods have significant advantages in that the level of risk is significantly reduced, as well as the level of expenditures on modernization information processes.

\section{Research results}

The main difference of information imperatives is a special attention to the intellectual abilities of the staff and the creation of conditions for the manifestation of these components when using productive forces. In socioeconomic terms, a large number of activities are being created to improve the skills of employees, create conditions for continuous training of team members and promote the development of relevant training technologies. 
It is a question of creating a triangle: information technology, legal regulation, and the intellectual potential of an organization [12].

A large number of scientific developments are devoted to technologies that appeal to informal knowledge, skills, transformation of existing knowledge into information components that allow to create an organization of a new type based on the methods, principles and modern information forms [14].

The question arises about the possibility of measuring the economic and social efficiency of information technology.

It is necessary to take into account two main areas that generally have different approaches:

- the first approach allows to evaluate the economic results when creating social events to improve the information support of the components in the personnel management system and is based on their own personal characteristics;

- the second approach includes innovative projects implemented by personnel, as well as an efficiency evaluation of social and economic projects at the operating enterprise to determine economic indicators of social activity, taking into account beta and gamma convergence. That is, microeconomic indicators are determined in the system of economic measurement of the social efficiency of relevant projects.

The possibilities for such assessments are specified by value indicators and the results of the production of innovative products or services. The determining factor in this system is the accounting of basic resources and factors of production. But the coverage of various fields of activity of the enterprise does not preclude the introduction of innovative technologies, but on the contrary is a component of valuations in the market price of the corresponding resources. The system of sectoral convergence allows to form an evaluation of the socio-economic efficiency of information technology in the short and long term [24].

Innovative technologies are compared with macroeconomic indicators and there is a gap between the bases for determining the existing indicators of the evaluation of economic efficiency, approved by the state, and the use of appropriate technologies based on macroeconomic indicators.

This formulation of the question, in which social and economic efficiency becomes beyond the limits of constraints, is an incentive to view the adequacy of assessments of the results of introducing information technologies in a practical plane.

The main indicators that relate to the results of the implementation of innovative technologies based on an extensive information network act as constraints and are poorly represented in the indicators for determining the efficiency of socio-economic projects.

In this regard, an important question arises about the implementation of new approaches to efficiency evaluation of socio-economic projects based on the introduction of information technologies, taking into account economic, financial, production, marketing and transactional indicators in the assessment system [17]. Therefore, it is necessary to take into account modern changes that are occurring to ensure the sustainable development of the state. When constant transitions are made to the effective development of an organization on the basis of an extensive information system, it is necessary to transform all management systems and components of a stable life activity of an organization into the plane of information cycles of reproduction of productive forces and corresponding resources. Such a new stage of informatization of the system of management decision-making arises as a fundamental principle in the information imperatives of the socio-economic development of each enterprise, organization, corporation, etc. [18].

This principle should be created on the new information platform, taking into account modern social integration processes in the plane of the development of sectoral convergences of the economic and informational component. It is necessary to note the integral component of the informatization of modern knowledge about the main processes of the technological plan, that is, modern planning, logistics, organization, modern control, which provide high quality management decisions. This component should be taken into account in the activities of all types of production and the emergence of the need for information and analytical direction of intervention in the management system of both the top management of the organization and the state. An objective need arises in the formation of state imperatives both at the level of the growing regulatory role of the state, and at the level of the top management of an enterprise organization.

The modern system of values for the progressive development of an organization includes fundamental qualitative changes in the level of information support, the development of transactional communications, which are transformed into the intellectual information property of each organization and provide predictive and strategic management with an orientation to socio-economic development. The value components of a modern enterprise are necessarily based on economic, social and spiritual platforms, which allow the formation of goal-oriented management [19].

Development of a modern enterprise based on an information platform:

- ensures sustainable economic growth, increase in labor productivity due to continuous training of personnel and corresponding expenses of the enterprise for the development of the intellectual component;

- the cost of main production is significantly reduced using high-tech technologies;

- quality management system is provided.

The social development platform is based on solving social and economic problems at the micro and macro levels and ensures a sustainable high level of management system in the organization and improving the welfare of the population. The spiritual component includes the support of a balanced and holistic development of the organization, while ensuring a high level of corporate culture, a significant increase in the level of education, as well as a high creative potential of each person [20].

The overall progress in the implementation of the information platform to ensure high rates of research activity in Ukraine is significantly higher than in other countries of the world.

The national methodology for the harmonization of information systems requires a transition to other indicators of the implementation of information technology, and as a result, a new assessment of the quality of scientific communications. The citation statistics and the total number of references to the scientific works of authors from different countries emphasize the importance of the scientific 
heritage of Ukrainian scientists on the informatization of modern management.

The creation of an information mechanism for the generation of high innovative activity of staff, the constant strengthening of the education system and retraining within the organization, that is, with substantial funding of all educational activities carried out by a modern organization, ensures the creation of a high level of business climate.

The introduction of modern information technologies significantly increases the competitiveness of innovative products, there is a significant encouragement of staff development, capitalization of intellectual potential occurs in the framework of the use of modern technologies. It also increases investment in the creation of new technologies on a global scale in order to integrate modern information technologies and the ability to ensure their stable development [21].

On the basis of the information and innovation paradigm, the formation of public-private partnership partnerships is taking place. Strengthening the national information policy is aimed at creating the economic power of the state. The latest information technologies contribute to significant economic growth based on the development of sectoral convergence of modern information technologies [22].

When the unsatisfactory state of making management decisions occurs without the introduction of modern information technologies, the efficiency of scientific research is significantly reduced, and they negatively affect the receipt of a positive result in making management decisions.

This happens both at the micro level (organization, enterprise, corporation management), and at the macro level (local, regional, state administration).

These contradictions are in the plane of the development and implementation of information technologies of the organization of the enterprise itself, which is based on the justification of the modern concept of development, as well as with an adequate assessment of management decision-making in government structures.

When forming the intellectual component on the basis of modern information technologies, the number of creative people increases significantly, social relations are formed within the organization and fundamental qualitative changes occur in the integration of information, technological and humanitarian knowledge [25]. In the education system, in particular, in the departments where professional knowledge is formed and developed, strategic models of curricula and educational programs should be developed taking into account indicators of the sustainable development of enterprises, industries, and the state based on modern information technologies.

Refining the concept of sustainable development and taking into account the features of these models for various fields of activity (production, energy, transport, construction, etc.) is formed on a series of textbooks, textbooks, monographs aimed at shaping the modern outlook of the individual. The unified information network of educational institutions in different countries allows developing a system for diagnosing the efficiency of an information network and monitoring the socio-economic situation in the world, country, region, and local community.

Modern information processes generate new challenges in the efficiency of the socio-economic development of the state and highlight the tension in assessing and measuring the integral indicator - the level of informatization per capita. The efforts of various institutions of society, as well as the formation of the requirements of various social movements, show how dependent the choice of the path of development of informatization and the level of advancement of these problems from the political situation [26].

The information culture has a particular importance as a paradigm in crisis management and, in some cases, the degradation of educational processes without the use of modern information technologies. This is due to the fact that modern challenges to the development of society, which arise from the restructuring of a fundamentally new paradigm in the plane of the knowledge economy, create a new system of motivation to work. Such changes that are occurring now, in the creation of traditional industrial transformations associated with the crucial role of mineral resources, the construction of large buildings. But in the formation of production costs, in the modern period, information technologies and a high intellectual level of personnel play a decisive role.

Social progress involves the use in the production of information and intelligent media. In this direction there is a special type of personality - the modern leader. Its main capital is modern managerial and organizational knowledge. The priority is the creative thinking of the strategic type. As a result, transactional communications between the object and the subject of market relations are radically changing. In the modern period of the economy, the cultural component is dominant in the development of civilization.

This provision is the creation of a doctrine for modern state imperatives of the socio-economic development of the country [27]. In the progressive system of modern management there is awareness that the loss of ties with the development of society on the basis of a significant decline in the cultural and spiritual component gives rise to contradictions between the individual. Such contradictions are the cause of the imbalance of the worldview and lead to growing social disasters. This is a problem that changes the values and spiritual principles associated with the degradation of the individual, significant despair and adaptation of the person.

Planning activities of social reproduction and the personality of the labor potential are the dominant challenges in many countries of the world. Scientific studies indicate the beginning of the formation of a new culture based on new types of social relations, created with the formation and equal access to modern information systems. Providing such access, according to the deep conviction of most scientists, creates a higher level of human development as well as corporate culture within the organization [28].

The formation of a new culture, based on increasing the requirements for individual self-development, in the new economic paradigm of partnership provides for an increase in the requirements for qualifications, professional competence, on the platform of modern social responsibility with general human moral values. But the globalization of political, economic, social and cultural processes in the modern world gives rise to a large number of problems of human survival. In the context of changes in the social attitudes of the individual and society, there is a significant reorientation of a person from the ideological growth to consumer values and spiritual degradation. A significant contribution to the formation of the information mechanism is the direction that confirms the significant growth of 
highly skilled labor with the use of information technologies and the corresponding increase in expenditures on the formation of human capital. Such a strategy requires the development of innovative information technologies and significantly improves the solution of social issues.

The formation of a large information network on the systems of educational activities that contribute to the improvement of personality development in the direction of the formation of leadership skills, an increase in competence components allows to raise the level of corporate culture. The success of such work provides an effective mechanism for the development and reproduction of labor resources, as well as the improvement of the intellectual component of the person, as the main factor of information technology development.

\section{SWOT analysis of research results}

Strengths. The strengths of the research allow to determine the possible deviations from the creation of an effective information network from the creation of socioeconomic projects and allow to obtain a positive result from the integration of existing information systems in other areas. When making comparisons, a program-oriented control method is implemented, it allows predicting possible deviations from the planned indicators and, accordingly, correcting the main process of creating an information network.

The proposed methods lead to a reduction in the cost of creating an information network and allow to form a platform for the future implementation of new projects for socio-economic development.

Weaknesses. The analysis carried out on the implementation of socio-economic projects for various groups of the population and the result obtained by assessing the quality of the activities carried out allow to show the high efficiency and multidimensionality of such projects. But due to the constantly changing endogenous and exogenous factors, it is very difficult to foresee possible deviations and plan activities that will ensure a sustainable result.

Opportunities. It is necessary to determine the complexity of the management system of socio-economic projects in connection with unstable financing and variable objectives of projects in accordance with unstable political conditions.

It is possible to form mathematical dependencies on the definition of possible changes, but it is difficult to flexibly implement such models to a wide range of socioeconomic projects when creating a unified information network.

Threats. The implementation of socio-economic projects is a variety of complex technologies that reduce the complex social conditions of the village, city, regional level of people's livelihoods, so there is not always public confidence in the future positive changes in the implementation of socio-economic projects.

\section{Conclusions}

1. It is established that information technologies are assets that need to be created taking into account exogenous and endogenous factors and be introduced into the modern management system of the socio-economic development of the state. The level of efficiency of information technology provides significant competitive advantages based on a sectoral convergence system. The main stages of informatization of the system include:

- the first stage is the adoption of management decisions and arises as a fundamental principle in the information imperatives of socio-economic development at the micro and macro levels;

- at the second stage, value components are formed, based on economic, social and spiritual platforms, and this allows the formation of goal-oriented management of socio-economic development.

2. It is revealed that in the context of an extensive information network, the organizational component is of particular importance. The paper proves that for the efficiency of the implementation of modernization changes in the system of modern information processes, the organizational component provides significant competitive advantages of the modern enterprise management system.

3. It is shown that the main task of implementing modernization processes is a system of sectoral convergences. This allows to form an evaluation of the socioeconomic efficiency of information technology in the short and long term. The foundation of modernization changes is the formation of information imperatives.

\section{References}

1. Shchokin H. V. Zakony sotsialnoho rozvytku i upravlinnia. Kyiv: MAUP, 2006. 192 p.

2. Chau J. Informational Uniqueness, Corporate Disclosure, and Information Environment // SSRN Electronic Journal. 2016. doi: http://doi.org/10.2139/ssrn.2753147

3. Vilyugka R. B. Factors affecting organizational structure in the system of investment management companies // Investments: Practice and Experience. 2013. Vol. 20. P. 47-52.

4. Möller J., Von Rimscha M. B. (De)Centralization of the Global Informational Ecosystem // Media and Communication. 2017. Vol. 5, Issue 3. P. 37. doi: http://doi.org/10.17645/mac.v5i3.1067

5. Koriakina A. A. Multicultural Informational and the Educational Environment of the University // Educational Process: International Journal. 2016. Vol. 5, Issue 4. P. 293-297. doi: http://doi.org/10.22521/edupij.2016.54.3

6. Wu K., Brenner J. Philosophy of Information: Revolution in Philosophy. Towards an Informational Metaphilosophy of Science // Philosophies. 2017. Vol. 2, Issue 4. P. 22. doi: http:// doi.org/10.3390/philosophies2040022

7. Kovalchuk K. F., Bandorina L. M., Savchuk L. M. Otsinka efektyvnosti informatsiino-intelektualnykh tekhnolohii. Dnipropetrovsk: IMA-pres, 2007. $132 \mathrm{p}$.

8. Introduction article: informational governance and environmental sustainability / Soma K. et. al. // Current Opinion in Environmental Sustainability. 2016. Vol. 18. P. 131-139. doi: http://doi.org/10.1016/j.cosust.2015.09.005

9. Shevchenko V. Yu. Hlobalna informatsiina ekonomika ta konkurentozdatnist natsionalnoho vyrobnytstva // Teoretychni ta prykladni pytannia ekonomiky. 2005. Vol. 6. P. 58-63.

10. Ostafiychuk P. G., Borkovich I. P. The analysis of modern methodological approaches of statistic evaluation of interconnections in economics // Scientific and Information Bulletin. Economics. 2015. Vol. 11. P. 309-314.

11. Bergemann D., Morris S. Belief-Free Rationalizability and Informational Robustness // SSRN Electronic Journal. 2016. doi: http://doi.org/10.2139/ssrn.2887380

12. Didyk A. M. Polivektornyi rozvytok pidpryiemstv: sotsialnoekonomichni ta rehuliatyvni aspekty. Lviv: Halytska Vydavnycha Spilka, 2016. 342 p.

13. Ortoll E., Cobarsí-Morales J. The Future of Our Informational Environment // Bulletin of the Association for Information Science and Technology. 2016. Vol. 43, Issue 2. P. 11-12. doi: http://doi.org/10.1002/bul2.2017.1720430206 
14. Fedulova I. V. Sutnist kontseptsii innovatsiinoho menedzhmentu z pozytsii upravlinnia znanniamy // Naukovi pratsi Odeskoho natsionalnoho universytetu kharchovykh tekhnolohii. 2008. Issue 33. P. 224-230.

15. Gavilan D., Martinez-Navarro G., Fernández-Lores S. University Students and Informational Social Networks: Total Sceptics, Dual Moderates or Pro-Digitals // Comunicar. 2017. Vol. 25, Issue 53. P. 61-70. doi: http://doi.org/10.3916/c53-2017-06

16. Shaw J., Graham M. An Informational Right to the City? Code, Content, Control, and the Urbanization of Information // Antipode. 2017. Vol. 49, Issue 4. P. 907-927. doi: http://doi.org/ 10.1111/anti.12312

17. Reshetylo V. P., Naumov M. S., Fedotova Yu. V. Transformatsiini protsesy v suspilstvi v umovakh informatsiinoi ekonomiky. Kharkiv: KhNUMH, 2014. 275 p.

18. Shvidanenko G. O. Imperatives of the enterprise development // Strategy of economic development of Ukraine. 2014. Vol. 35 P. $23-28$.

19. Karpenko O. O., Babina O. Y. Integration as an imperative of contemporary economy development // Actual problems of the economy. 2014. Vol. 3, Issue 153. P. 22-30.

20. Amosha O. Innovatsiinyi shliakh rozvytku Ukrainy: problemy ta rishennia // Ekonomist. 2005. Issue 6. P. 28-32.

21. Zharinova A. H. Metodolohiia upravlinnia intelektualnym kapitalom v umovakh stanovlennia informatsiinoi ekonomiky. Kyiv: Nichlava, 2013. 323 p.

22. Kuzmin O., Petryshyn N., Syrotynska N. Nova paradyhma pobudovy system menedzhmentu // Naukovyi visnyk «Demokratychne Vriaduvannia». 2010. Vol. 6. P. 75-82.
23. Holden E., Linnerud K., Banister D. The Imperatives of Sustainable Development // Sustainable Development. 2016. Vol. 25 , Issue 3. P. 213-226. doi: http://doi.org/10.1002/sd.1647

24. Illyashenko S. M. Management of innovative development: problems, concepts, methods. Sumy: VTD «University Book», 2003. 278 p.

25. Ishchuk S. O. Intelektualizatsiia yak svitova tendentsiia ekonomichnoho rozvytku // Visnyk Universytetu bankivskoi spravy NBU. 2011. Issue 2 (11). P. 91-95.

26. Zharinova A. H. Mekhanizm upravlinnia intelektualnym kapitalom v umovakh innovatsiinoho rozvytku ekonomiky Ukrainy // Formuvannia rynkovykh vidnosyn v Ukraini. 2015. Issue 1 (164). P. $44-46$

27. Herasymchuk V. H. Rol derzhavy v zabezpechenni konkurento-spromozhnosti promyslovoho vyrobnytstva $\mathrm{v}$ umovakh transformatsii svitovoi ekonomiky // Rynkovo-oriientovane upravlinnia innovatsiinym rozvytkom. Kharkiv: TOV «Disa plius», 2015. P. 110-120.

28. Kvach Ya. P., Shaposhnykov K. S., Adamkovych M. M. Korporatyvne upravlinnia orhanizatsiinym rozvytkom: kreatyvni zasady. Izmail: SMIL, 2008. 272 p.

Pishenina Tatiana, Doctor of Economic Sciences, Professor, Head of the Department of Management and Public Administration, Kyiv Institute of Business and Technology, Ukraine, e-mail: pishenina@ukr.net, ORCID: http://orcid.org/0000-0002-0434-5407

Vlasova Katerina, Postgraduate Student, Department of Management, Open International University of Human Development «Uk raine», Kyiv, Ukraine, e-mail:93705@ukr.net, ORCID: http://orcid.org/ 0000-0001-7273-9021 